\title{
Effect of Late-Term Subclinical Cardiotoxicity on Functional Exercise Capacity of Pediatric Cancer Survivors who were Treated with Anthracyclines
}

\author{
Antrasiklinlerle Tedavi Edilmiş Pediatrik Kanser Hastalarında Uzun \\ Dönemde Gelişen Subklinik Kardiyotoksisitenin Fonksiyonel Egzersiz \\ Kapasitesi Üzerine Etkisi
}

\author{
Mehmet Kenan KANBUROĞLU1', Fatma Sedef TUNAOĞLU², Güçlü PINARLI, Ceyda KARADENIZ³ \\ Aynur OĞUZ³ , Ayşe YILDIRIM4, Serdar KULA², Deniz OĞUZ², Rana OLGUNTÜRK²
}

\begin{abstract}
${ }^{1}$ Dr. Nafiz Körez Sincan State Hospital, Department of Pediatrics, Neonatal Unit, Ankara, Turkey
${ }^{2}$ Gazi University, Faculty of Medicine, Department of Child Health and Diseases, Pediatric Cardiology Department, Ankara, Turkey ${ }^{3}$ Gazi University, Faculty of Medicine, Department of Child Health and Diseases, Children's Oncology Department, Ankara, Turkey

${ }^{4}$ Kartal Koşuyolu Training and Research Hospital, Department of Children's Cardiology, Istanbul, Turkey
\end{abstract}

\begin{abstract}
Objective: We aimed to evaluate the functional exercise capacity and its relation to echocardiographic measurements in pediatric cancer survivors who were treated with anthracyclines.

Material and Methods: Sixteen patients who completed chemotherapy 9-16 years ago and who have no symptoms of heart failure were enrolled in the study, together with 16 healthy subjects. Ejection fraction, fractional shortening, and myocardial performance index were calculated by echocardiographic evaluation. Patients with a myocardial performance index $>0.37$ were accepted as having subclinical cardiotoxicity. Functional exercise capacity was evaluated by the sixminute walk test.

Results: Patients had significantly higher values of myocardial performance index than control subjects $(p<0.001)$. The six-minute walking distance was found to be lower in patients than that of the control subjects $(p=0.02)$. Furthermore, in patients with subclinical cardiotoxicity, the difference was more significant $(p=0.001)$. Six minute walking distance and myocardial performance index were well correlated with each other $(r=-0.6 p=0.03)$ and with cumulative anthracycline dosage ( $r=-0.6 p=0.04$ and $r=0.6 p=0.02$ respectively).

Conclusion: Long-term pediatric cancer survivors may have subclinicalcardiotoxicity despite having no clinical symptoms. Patients with subclinical cardiotoxicity should be taken into account for having impaired functional exercise capacity and correspondingly low quality of life. Six-minute walk test could be a useful indicator for subclinical cardiotoxicity since it is well correlated with myocardial performance index.
\end{abstract}

Key Words: Activities of daily living, Anthracycline, Cancer, Children, Quality of life

\section{ÖZET}

Amaç: Çalışmada antrasiklin kullanılarak tedavi edilmiş pediatrik kanser hastalarının uzun dönem takiplerinde görülebilen subklinik kardiyotoksisite ile fonksiyonel egzersiz kapasitesi arasındaki ilişki incelenmiştir.

Gereç ve Yöntemler: Kemoterapi tedavisi 9-16 yı önce tamamlanmış ve kalp yetmezliği bulguları olmayan 16 hasta ile 16 sağlıklı kontrol çalışmaya alındı. Ejeksiyon fraksiyonu, fraksiyonel kısalma ve miyokardiyal performans indeksi ölçümleri ekokardiyografik olarak alındı. Subklinik kardiyotoksisite açısından miyokardiyal performans indeks sınırı 0.37 olarak kabul edildi. Fonksiyonel egzersiz kapasitesi 6-dakika yürüme testi ile değerlendirildi.

Bulgular: Hastaların miyokardiyal performans indeks değerleri belirgin olarak kontrol grubundan daha yüksek saptandı ( $p<0.001)$. 6-dakika yürüme testi mesafesi kontrol grubuna göre hastalarda daha kısa ölçüldü ( $p=0.02)$; özellikle subklinik kardiyotoksisitesi olan hastalarda bu fark daha belirgindi ( $p=0.001)$. 6-dakika yürüme testi ile miyokardiyal performans indeksi arasında iyi bir korelasyon bulunduğu gibi $(r=-0.6 p=0.03)$ kümülatif antrasiklin dozu ile bu iki değer arasında da anlamlı korelasyon saptandı (sırasıyla $r=-0.6 p=0.04$ ve $r=0.6 p=0.02$ ).

Correspondence Address / Yazışma Adresi :

Mehmet Kenan KANBUROĞLU

Dr. Nafiz Körez Sincan Devlet Hastanesi, 12. Cadde Semt Polikliniği, Yenidoğan Servisi, Sincan, Ankara, Turkey

E-mail: drkenankan@hotmail.com
Received / Geliş tarihi : : 31.01.2015 Accepted / Kabul tarihi : 03.04.2015

Online published 22.06.2015

Elektronik yayın tarihi

DOI: 10.12956/tjpd.2015.160 
Sonuç: Tedavisi tamamlanmış pediatrik kanser hastalarının uzun dönem takiplerinde klinik bulgu olmaksızın subklinik kardiyotoksisite görülebilmektedir. Fonksiyonel egzersiz kapasitesinin ve bunun sonucunda yaşam kalitesinin düşmesiyle sonuçlanabileceğinden subklinik kardiyotoksisite önemsenmesi gereken bir durumdur. 6-dakika yürüme testi ve miyokardiyal performans indeksi arasında iyi bir korelasyon olduğundan subklinik kardiyotoksisite açısından bir belirleyici olarak kullanılabilir.

Anahtar Sözcükler: Günlük aktiviteler, Antrasiklinler, Kanser, Çocuklar, Hayat kalitesi

\section{INTRODUCTION}

More than $\mathbf{2 0 0 . 0 0 0 ~ n e w l y ~ d i a g n o s e d ~ c h i l d h o o d ~ c a n c e r ~ c a s e s ~}$ are seen each year, and this figure is expected to double in the next 20 years (1). The childhood cancer survival rate was $40 \%$ in the 1970 s, whereas it exceeds $70 \%$ today (1). However, long-term health consequences of the treatments have come to the forefront (2). Anthracyclines are one of the major chemotherapeutics used in the treatment of more than $60 \%$ of the childhood cancers; nevertheless, cardiotoxic side effects limit their use (2). Kremer et al. (3) reported that 5\% of children given anthracyclines for malignancies developed clinical heart failure within 15 years. Long-term complications can be minimized with early interventions (2).

Echocardiography is currently the most commonly used test to screen late cardiac toxicity even though cardiac magnetic resonance imaging may identify a high prevalence of cardiomyopathy among adult survivors $(4,5)$.

Echocardiographic parameters such as myocardial performance index (MPI), interventricular septum thickness and left ventricular posterior wall thickness have been shown to be impaired even in patients with no clinical cardiotoxicity $(6,7)$. These echocardiographic findings were thought to be the early signs of late cardiotoxicity, and are referred to as subclinical cardiotoxicity. It is important to understand whether these echocardiographic findings may imply any difficulty in the conduct of activities of daily living and to be able to identify those patients at risk of developing late cardiotoxicity.

The six-minute walk test (6MWT) is an easy, inexpensive and brief method to test functional exercise capacity (8). It is a submaximal exercise test that represents the exercise capacity for activities of daily living and the patient's quality of life more reliably than other complicated exercise tests, such as the Bruce protocol (9). In this study, we tried to evaluate the impact of echocardiographic findings on functional exercise capacity of pediatric cancer survivors who were treated with anthracyclines by using the six-minute walk test,

\section{METHODS}

This case-control study was conducted at the University Medical School between January 2009 and October 2010. Sixteen (11 male, 5 female) patients treated with anthracycline for cancer, and their age, sex and anthropometrically (weight, height) matched healthy controls ( $\mathrm{n}$ : 16) were enrolled. Anthracycline treatment protocols were similar for every patient: daily, 20-45 $\mathrm{mg} / \mathrm{m} 2$ anthracycline administered via 6-8-hour infusion within 2-3 days for a total of $60-90 \mathrm{mg} / \mathrm{m} 2$ in each cycle. The combined anthracycline dosage was calculated based on the doxorubicin isotoxic equivalent dose by using the conversion factors that were specified in the Children's Oncology Long-term Follow-up Guidelines for Survivors of Childhood, Adolescent and Young Adult Cancers (10). Eleven of the patients ( 9 male, 2 female) also received vincristine treatment. Before subject enrollment, the study protocol was reviewed and approved by the local Institutional Human Subjects Research Review Board. Informed consent was obtained from the children's parents or caregivers and the participants themselves.

6MWT was performed according to guidelines of the American Thorax Society (8). The same examiner conducted the tests in order to eliminate any inter-operator differences. All subjects were informed about the test the day before admission; thus, they were all in comfortable clothes and normal satiety. Before starting the test, vital signs (pulse oxygen saturation by PlusMED Model Plus-50C, respiratory rate, cardiac rates and blood pressure) and anthropometric measurements (weight, height) were obtained by using the same devices for all subjects. The children were encouraged by the examiner, who walked alongside them and gave predetermined identical verbal commands every minute to walk as far as possible in a 30-meter corridor for six minutes. At the end of the test, the vital signs of the subjects were measured again. The heart rate acceleration ratio was calculated as the percentage of the increment in the heart rate before and after the test. Li et al.(11) reported that there is a lack of intersubject variability in the sixminute walk test; therefore, the test was not repeated.

For echocardiographic evaluation, GE-Vingmed Vivid 7 Pro (Horten, Norway) equipment with a $5 \mathrm{MHz}$ transducer was used. Transthoracic echocardiography was performed with the patients lying in the supine or left lateral position. Parasternal long and short-axis and apical 4-chamber views were recorded. The mean values of these measurements, recorded from three consecutive observations, were used for statistical analysis. Standard M-mode recordings of the left ventricle (LV) were obtained. Interventricular septum thickness at end systole and diastole (IVSs and IVSd), LV posterior wall thickness at end systole (LVPWs) and at end diastole (LVPWd), and LV dimension at end systole (LVSD) and at end diastole (LVDD) were measured. LV end diastolic and systolic volumes (LVDV and LVSV) were calculated using "Recommendations for chamber quantification" (modified Simpson's rule) (12). 
Fractional shortening (FS) and ejection fraction (EF) were calculated as FS: (LVDD - LVSD/LVDD) × 100 and EF: (LVDV LVSV/LVDV) $\times 100$

The pulsed-wave Doppler sample volume was placed at the tip of the mitral leaflet $1 \mathrm{~cm}$ above the plane of the mitral annulus. Mitral early diastolic flow $(E)$ velocity and late diastolic flow $(A)$ velocity, ejection time (ET), isovolumetric relaxation time (IVRT), and isovolumetric contraction time (IVCT) were measured from an apical four-chamber view. The myocardial performance index (MPI) was calculated using the formula:

$\mathrm{MPI}=(\mathrm{IVCT}+\mathrm{IVRT}) / \mathrm{ET}$ (13).

Patients with MPI values greater than 0.37 (87\%) were accepted as having subclinical cardiotoxicity since the upper limit of MPI in pediatric and young ages has been reported as $0.37(6,14)$. The same cardiologist who was blinded to the results of the sixminute walk test evaluated all echocardiograms. None of the patients was anemic on routine follow-up investigations.

\section{Statistical Analysis}

Data are presented as median (maximum and minimum) for continuous variables, and as absolute or relative frequencies and percentage for categorical variables. The Mann-Whitney $U$ test was used for comparison of continuous variables to measure differences between the patients and controls. Spearman's Test was used for inspecting the correlation between MPI and cumulative anthracycline dosage; however, partial correlation corrected for gender and height was used for correlations between 6MWT, MPI and cumulative anthracycline dosage since $6 \mathrm{MWT}$ is substantially influenced by these variables. A $p$ value $<0.05$ was considered significant based on two-tailed tests. Descriptive analysis of data and analysis of variance were undertaken using the Statistical Package for the Social Sciences (SPSS) 13.0 for Windows program (SPSS, Chicago, IL).

\section{RESULTS}

Patients and healthy subjects were matched according to age, sex, and anthropometric measurements. Descriptive features of the two groups are summarized in Table I. Patients were treated for Hodgkin's lymphoma, non-Hodgkin lymphoma, Wilms' tumor, ganglioneuroblastoma, angiosarcoma, rhabdomyosarcoma, and hepatoblastoma. They received doxorubicin, daunorubicin, and epirubicin, culminating in a cumulative anthracycline dosage of $90-480 \mathrm{mg} / \mathrm{m}^{2}$ (median 240). Time spent from last chemotherapeutic dose was 9-16 (median $=13$ ) years. Patients were aged $1-15$ years at the first diagnosis (median=6) and 13-26 years (median= 18 ) at the time of the study. One of the patients was treated with epirubicin only, and one of them received both epirubicin and doxorubicin. Two other patients also received mediastinal radiotherapy (1800-2000 cGy). For all the remaining patients, doxorubicin was the treatment of choice.
All subjects had normal values for EF and FS, and none of the patients had symptoms of heart failure (Table II). Cancer survivors had higher MPI than control subjects (Median=0.41 and 0.34 respectively, $p=0.001$ ) (Figure 1). All the control subjects and two of the patients had MPI values $<0.37$. Subclinical cardiotoxicity (MPI of $>0.37$ ) was present in $87 \%$ of the patients.

Heart rate acceleration ratio, respiratory rate and oxygen saturation of the subjects before and after the tests were not different between the control group and patients. The six-minute walking distance was not different between genders. The sixminute walking distance of control subjects (median: 570 meters) was longer than that of patients (median: 500 meters, $p=0.020$ ); furthermore, the difference was more significant with the patients having subclinical cardiotoxicity (median: 491 meters, $p=0.001$ ) (Table II).

Six minute walking distance and myocardial performance index were well correlated with each other $(r=-0.6 p=0.03)$ and with cumulative anthracycline dosage $(r=-0.6 p=0.04$ and $r=0.6 p=$ 0.020 respectively).

\section{DISCUSSION}

With an increasing number of survivors among pediatric cancer patients, maintaining quality of life and timely diagnosis of the late-onset complications have become the focus of care (15). Developing strategies for the clinical follow-up of longterm survivors is essential (15). Easy and low-cost modalities are needed in these patients since the follow-up may last lifelong (2). It has been discovered that costs force young cancer survivors to miss follow-up care since most expenses are not covered by their insurance (16). However, none of the guidelines

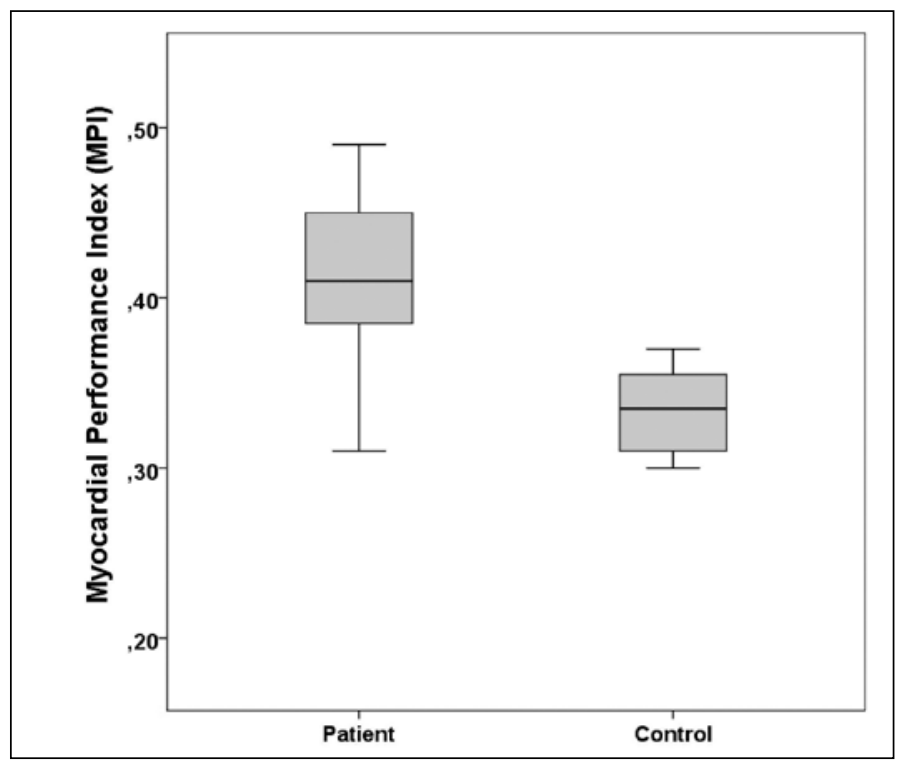

Figure 1: Myocardial performance index (MPI) values of patients and controls. 
specify how often and by which parameters cancer survivors should be followed (4). The six-minute walk test is a practical test that requires no exercise equipment or advanced training for technicians, but there is little experience with its usage in childhood cancer patients.

Previous studies have revealed that exercise capacity can be reduced in apparently healthy survivors of cancer by using diverse exercise tests including 6MWT (17-20). However, this is the first study showing that an increased MPI may represent a reduced six-minute walk distance and hence the quality of life to the best of our knowledge.

Echocardiography and MUGA (MUltiple Gated Acquisition scan) are the recommended instruments for screening cardiac functions of childhood cancer survivors (21). The frequency of the late subclinical cardiotoxicity, defined in terms of abnormal findings on echocardiography, has been reported to be as high as 57\% among childhood cancer survivors (22). Several reports indicate that measurements such as MPI, the ratio between early and late ventricular filling velocity and tissue velocity imaging in early diastole enable the early detection of subclinical changes in cardiac function, although their predictive value is unclear $(6,23)$. Our echocardiographic results were similar to those

Table I: Descriptive features of the subjects.

\begin{tabular}{l|c|c|c}
\hline & $\begin{array}{c}\text { Patients } \\
\text { Median } \\
\text { (Min-Max) }\end{array}$ & $\begin{array}{c}\text { Control } \\
\text { Median } \\
\text { (Min-Max) }\end{array}$ & $\begin{array}{c}\text { p } \\
\text { Value }\end{array}$ \\
\hline Age, years & $18(13-26)$ & $18(13-26)$ & NS \\
\hline Gender & 11 males, & 11 males, & NS \\
\hline Weight (kg) & $61(48-80)$ & $59(49-76)$ & NS \\
\hline Height (cm) & $166(153-176)$ & $167(157-176)$ & NS \\
\hline BMI & $21.6(18.4-28.9)$ & $21.9(17.2-25.1)$ & NS \\
\hline
\end{tabular}

BMI: Body mass index, Max: maximum, Min: minimum, NS: nonspecific of recent studies, which have shown that MPI was elevated in long-term survivors of cancer. By means of the 6MWT, patients with $\mathrm{MPI}>0.37$ had lower functional exercise capacity and may therefore have a low quality of life. Patients with MPI values greater than 0.37 walked 94 meters less than those with lower MPI. De Caro et al. (17) reported a series of 55 patients in which $30 \%$ of the patients treated with anthracyclines had subclinical cardiotoxicity. However, this did not significantly affect the cardiopulmonary exercise performance of these patients, possibly due to the short follow-up period (mean: 6.4 years) of the study. It is known that the incidence of cardiac abnormalities in patients exposed to anthracyclines increases over time, reaching more than half of the patients at 10-20 years from the date of diagnosis (24). Therefore we tried to attain the longest possible follow-up period implementable at our clinic. On the other hand, we did not include younger subjects although they may be disease free for more than five years due to rapid changes in 6MWD before the age of 12 (25).

Hartman et al. (20) demonstrated that although the motor performance had improved in the recovery period following chemotherapy, the 6MWT was significantly impaired in the follow-up of survivors of pediatric acute lymphoblastic leukemia. Nevertheless, the exact underlying cause of the impairment in $6 \mathrm{MWT}$ was not investigated in the study.

The 6MWD of both the control subjects and patients of our study were between the normal ranges (5th -95th percentile) according to their age except 3 patients whose 6MWD values were lower than 5th percentile and MPI values were 0.41, 0.45 and 0.45 exactly (26). There was no subject having a low 6MWD with a normal MPI, making 6MWT a potential candidate for screening patients for a comprehensive examination.

The 6MWT evaluates the global and integrated responses of all the systems involved during exercise, including the pulmonary, cardiovascular and neuromuscular systems. Accordingly, a low 6MWD does not indicate an impaired heart function solely; it warns against a diminished functional exercise capacity. Cardiac toxicity is probably the first suspected reason to

Table II: Echocardiographic parameters and six minute walking distance of the subjects.

\begin{tabular}{|c|c|c|c|c|}
\hline & \multicolumn{2}{|c|}{$\begin{array}{c}\text { Patients } \\
\text { Median (Min-Max) }\end{array}$} & $\begin{array}{c}\text { Control } \\
\text { Median (Min-Max) }\end{array}$ & p Value \\
\hline Ejection Fraction & \multicolumn{2}{|c|}{$69(62-76)$} & $69(65-88)$ & NS (0.36) \\
\hline Myocardial Performance Index & \multicolumn{2}{|c|}{$0.41(0.31-0.49)$} & $0.34(0.30-0.37)$ & $<0.001$ \\
\hline \multirow{2}{*}{ Six Minute Walking Distance (meter) } & \multicolumn{2}{|c|}{$500(386-623)$} & $570(490-653)$ & 0.020 \\
\hline & $491(386-623)$ & $601(584-618)$ & $570(490-653)$ & $0.001^{\star}$ \\
\hline Anthracycline Dosage $\left(\mathrm{mg} / \mathrm{m}^{2}\right)$ & \multicolumn{2}{|c|}{$270(90-480)$} & - & - \\
\hline
\end{tabular}

*: comparison of six minute walking distance between patients having MPl>0.37 and control subjects. Max: maximum, Min: minimum, MPI: myocardial performance index, NS: non-specific. 
explain reduced functional exercise capacity in survivors of pediatric cancer who were treated with anthracyclines. In this study, we did not comprehensively investigate the participants with sophisticated tests as a component of the study protocol; however all patients had normal chest $\mathrm{x}$-rays, spirometry measurements, and neurological examinations during routine follow-up investigations.

Some confounding factors may alter the GMWD in the present study. Vincristine has neuromotor toxicity whereas it may also attenuate doxorubicin cardiotoxicity (27). On the other hand, radiation therapy to the chest may cause lung toxicity, which may decrease 6MWD (28).

One of the weak points of our study was the small sample size, which can be attributed to the difficulty in reaching a cancer survivor so many years after the last chemotherapy. Furthermore, the 6MWT is an indirect indicator of quality of life; hence, detailed surveys questioning daily life routines are needed for detecting quality of life accurately.

In conclusion, pediatric cancer survivors having MPI values greater than 0.37 may have decreased submaximal exercise capacity, although they have no pathological findings on clinical examinations. The six-minute walk test could be a useful indicator to detect subclinical cardiotoxicity since it is well correlated with the myocardial performance index. The MPI and 6MWT may be utilized as follow-up evaluation methods in survivors of pediatric cancer to ascertain subclinical cardiotoxicity and impaired functional exercise capacity. Further prospective studies comprising larger sample sizes may reveal the significance of these methods in the follow-up of cancer survivors. Data revealed from these studies could be utilized to determine how exercise recommendations for cancer survivors should be.

\section{REFERENCES}

1. Steliarova-Foucher E, Stiller C, Kaatsch P, Berrino F, Coebergh JW, Lacour B, et al. Geographical patterns and time trends of cancer incidence and survival among children and adolescents in Europe since the 1970s (the ACCIS project): An epidemiological study. Lancet 2004;364:2097-105.

2. Curry HL, Parkes SE, Powell JE, Mann JR. Caring for survivors of childhood cancers: The size of the problem. Eur $\mathrm{J}$ Cancer 2006;42:501-8.

3. Kremer LC, van Dalen EC, Offringa M, Ottenkamp J, Voute PA. Anthracycline-induced clinical heart failure in a cohort of 607 children: Long-term follow-up study. J Clin Oncol 2001;19:191-6.

4. Altena R, Perik PJ, van Veldhuisen DJ, de Vries EG, Gietema JA. Cardiovascular toxicity caused by cancer treatment: Strategies for early detection. Lancet Oncol 2009;10:391-9.

5. Armstrong GT, Plana JC, Zhang N, Srivastava D, Green DM, Ness KK, et al. Screening adult survivors of childhood cancer for cardiomyopathy: Comparison of echocardiography and cardiac magnetic resonance imaging. J Clin Oncol 2012;30:2876-84.
6. Eidem BW, Sapp BG, Suarez CR, Cetta F. Usefulness of the myocardial performance index for early detection of anthracyclineinduced cardiotoxicity in children. Am J Cardiol 2001;87:1120-2.

7. Yildirim A, Tunaoglu FS, Kanburoglu MK, Pinarli FG. The utility of NT-proBNP and various echocardiographic methods in the determination of doxorubicin induced subclinical late cardiotoxicity. Kardiol Pol 2013;71:40-6.

8. American Thoracic Society. ATS statement: Guidelines for the sixminute walk test. Am J Respir Crit Care Med 2002;166:111-7.

9. Solway S. A qualitative systematic overview of the measurement properties of functional walk tests used in the cardiorespiratory domain. Chest 2001;119:256-70.

10. The Children's Oncology Group. Long-Term Follow-Up Guidelines for Survivors of Childhood, Adolescent, and Young Adult Cancers Version 3.0 [online]. Available from: http://www. survivorshipguidelines.org. Accessed 07.12.2014.

11. Li AM, Yin J, Yu CC, Tsang T, So HK, Wong E, et al. The six-minute walk test in healthy children: Reliability and validity. Eur Respir $J$ 2005;25:1057-60.

12. Lang RM, Bierig M, Devereux RB, Flachskampf FA, Foster E, Pellikka PA, et al. Recommendations for chamber quantification. Eur J Echocardiogr 2006;7:79-108.

13. Tei C, Ling LH, Hodge DO, Bailey KR, Oh JK, Rodeheffer RJ, et al. New index of combined systolic and diastolic myocardial performance: A simple and reproducible measure of cardiac function--a study in normals and dilated cardiomyopathy. J Cardiol 1995;26:357-66.

14. Jurko A, Jr Jurko A, Minarik M. Doppler-derived myocardial performance index in healthy children. Bratisl Lek Listy 2011;112:77-9.

15. Wallace WH, Blacklay A, Eiser C, Davies H, Hawkins M, Levitt GA, et al. Developing strategies for long term follow up of survivors of childhood cancer. BMJ 2001;323:271-4.

16. Kirchhoff AC, Lyles CR, Fluchel M, Wright J, Leisenring W. Limitations in health care access and utilization among longterm survivors of adolescent and young adult cancer. Cancer 2012;118:5964-72.

17. De Caro E, Fioredda F, Calevo MG, Smeraldi A, Saitta M, Hanau $\mathrm{G}$, et al. Exercise capacity in apparently healthy survivors of cancer. Arch Dis Child 2006;91:47-51.

18. Sato T, Harada K, Tamura M, Watanabe A, Ishii M, Takada G. Cardiorespiratory exercise capacity and its relation to a new Doppler index in children previously treated with anthracycline. J Am Soc Echocardiogr 2001;14:256-63.

19. Miller AM, Lopez-Mitnik G, Somarriba G, Lipsitz SR, Hinkle AS, Constine LS, et al. Exercise capacity in long-term survivors of pediatric cancer: An analysis from the Cardiac Risk Factors in Childhood Cancer Survivors Study. Pediatr Blood Cancer 2013;60:663-8.

20. Hartman A, Hop W, Takken T, Pieters R, van den Heuvel-Eibrink M. Motor performance and functional exercise capacity in survivors of pediatric acute lymphoblastic leukemia. Pediatr Blood Cancer 2013;60:494-9.

21. Landier W, Bhatia S, Eshelman DA, Forte KJ, Sweeney T, Hester $A L$, et al. Development of risk-based guidelines for pediatric cancer survivors: The Children's Oncology Group Long-Term FollowUp Guidelines from the Children's Oncology Group Late Effects Committee and Nursing Discipline. J Clin Oncol 2004;22:4979-90. 
22. Kremer LC, van der Pal HJ, Offringa M, van Dalen EC, Voute PA. Frequency and risk factors of subclinical cardiotoxicity after anthracycline therapy in children: A systematic review. Ann Oncol 2002;13:819-29.

23. Tassan-Mangina S, Codorean D, Metivier M, Costa B, Himberlin C, Jouannaud C, et al. Tissue Doppler imaging and conventional echocardiography after anthracycline treatment in adults: Early and late alterations of left ventricular function during a prospective study. Eur J Echocardiogr 2006;7:141-6.

24. Mulrooney DA, Yeazel MW, Kawashima T, Mertens AC, Mitby P, Stovall $\mathrm{M}$, et al. Cardiac outcomes in a cohort of adult survivors of childhood and adolescent cancer: Retrospective analysis of the Childhood Cancer Survivor Study cohort. BMJ 2009;339:b4606.
25. Ulrich S, Hildenbrand FF, Treder U, Fischler M, Keusch S, Speich R, et al. Reference values for the 6-minute walk test in healthy children and adolescents in Switzerland. BMC Pulm Med 2013;13:49.

26. Kanburoglu MK, Ozdemir FM, Ozkan S, Tunaoglu FS. Reference values of the 6-minute walk test in healthy Turkish children and adolescents between 11 and 18 years of age. Respir care 2014;59:1369-75.

27. Chatterjee K, Zhang J, Tao R, Honbo N, Karliner JS. Vincristine attenuates doxorubicin cardiotoxicity. Biochem Biophys Res Commun 2008;373:555-60.

28. Motosue MS, Zhu L, Srivastava K, Stokes DC, Hudson MM, McPherson $\mathrm{V}$, et al. Pulmonary function after whole lung irradiation in pediatric patients with solid malignancies. Cancer 2012;118: 1450-6. 